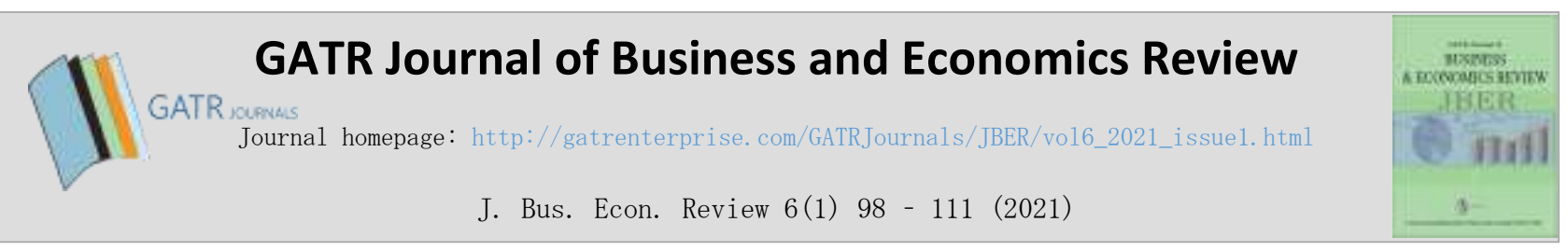

\title{
Trade Promotion from Thailand to China As A Result Of a New Train Route
}

\author{
Siyuan wei ${ }^{*}$, Vatcharapol Sukhotu ${ }^{2}$ \\ ${ }^{1}$ Naresuan University 99, Moo.9, Thapo sub-district, Mueang district, Phitsanulok province 65000, \\ Thailand \\ ${ }^{2}$ Naresuan University 99, Moo.9, Thapo sub-district, Mueang district, Phitsanulok province 65000, Thailand
}

\begin{abstract}
Objective - This paper aims to analyse the impact of the China-Laos railway on export trade from China to Thailand. The paper analyses the advantages and disadvantages of the new route and other routes base on driven factors, identifies what trade industry is suitable for this new route and provides some reference for Thai trade exporters. This will enable Thai export traders to understand the new transportation route formed by the railway and improve the trade volume and competitiveness of Thai products through this route.

Methodology/Technique - Literature review method, secondary data method, in-depth interview method.

Findings - It is found that the new route formed after the completion of the China-Laos railway has many advantages base on driven factors and many industries are suitable for the use of this new route.

Novelty - Few people know much about the China-Laos railway, and even less about the analysis of its impact on Thailand's trade. The author's in-depth interview method allows him to get in touch with experts who are very relevant to the China-Laos railway, providing valuable insights.

Type of Paper: Empirical.

JEL Classification: F16, F18, F19.

Keywords: Thai Products; Driving Factors; Route Selection; China-Laos Railway; In-depth Interviews; Secondary Data Method

Reference to this paper should be made as follows: Wei, S; Sukhotu, V. 2021. Trade Promotion from Thailand to China as a Result of a New Train Route, J. Bus. Econ. Review, 6(1), 98-111. https://doi.org/10.35609/jber.2021.6.1(3)
\end{abstract}

\section{Introduction}

Since the establishment of the China-ASEAN Free Trade Area in 2010, and with the development of economic globalization in recent years, the bilateral trade volume between China and Thailand has been increasing. China is Thailand's largest trading partner, whilst Thailand is China's third-largest trading partner among ASEAN countries (Bin \& Mengrong, 2018). In 2019, bilateral trade reached US $\$ 80$ billion, of which China's exports reached 50.98 billion USD, increasing by $1.6 \%$ every year, while imports reached 29.02 billion USD, which is down by $3.4 \%$ annually.

\footnotetext{
* Paper Info: Revised: March 15, 2021

Accepted: June 30, 2021

* Corresponding author: Siyuan wei

E-mail: 810086590@qq.com

Affiliation: Naresuan University, Thailand
}

Thailand's trade deficit with China is growing and increasing exports has also become a priority for Thailand's economic development. Plastic and rubber, mechanical and electrical products, and plant products 
are the three main categories of Thai products exported to China, mainly to Yunnan, Guangxi, Guangdong, Shanghai, and Shandong. Different export destinations will adopt a combination of land transportation, sea transportation, river transportation, and air transportation. China and Thailand are not neighbours, and Laos is an important intermediary country in the transportation process between the two countries.

The China-Laos railway is expected to be completed in December 2021. This will provide more efficient transportation of goods, running 18 trips daily: 14 trips for goods and 4 for passengers. The trade volume between China and Laos is small; Thailand's trade exports mainly rely on sea and land transport, so this new railway will primarily be used for China-Thailand trade. The completion of the Railway between China and Laos will form a new trade transportation route, and the railway will also become a new mode of transportation between China and Thailand (Yue, Duanfeng, Jihong \& Guoliang, 2014). Logistics performance is the main reason for Thailand's lack of competitiveness compared with Vietnam's industry and is an important factor affecting cross-border trade. The new transportation mode and route will improve the performance of logistics and transportation between China and Thailand and improve the core competitiveness of Thai products, thus increasing the export volume of Thai products.

Firstly, the author identifies which provinces export the bulk of Thailand's goods to and the export volume of these provinces through a literature review. Following this, the main export routes of Thai products to these provinces is summarised. Next, the secondary data method and in-depth interviews are used to determine the driving factors of route selection. Finally, qualitative analysis is used to analyse the advantages and disadvantages of the new route and other routes based on driving factors. The new route will have advantages in most factors; the Thai industry will have a better understanding of these routes, the performance of various factors of these routes, and will be able to use these new routes effectively. This will enable Thailand's export industry to improve its' logistical performance, thus improving the industry's export competitiveness and export volume.

\section{Literature review}

\subsection{China-Laos railway}

The literature review showed that there are few studies examining the China-Laos railway, and even fewer studies on the connection between China-Laos railway and Thailand's export trade. The author obtained some information about the railway by interviewing experts of the China-Laos railway project. The China-Laos railway connects Kunming, China, with Vientiane, Laos. The railway has a total length of more than 900 kilometers. The mainline in China has a length of 508.53 kilometers, and Laos has 414 kilometres (Zhangjie, Wang \& Zhang, 2019). The designed speed is 160 kilometers per hour. There are 7 stations in China's section (Figure 1) and 11 in Laos' section (Figure 2), with passenger train speeds of $160 \mathrm{~km} / \mathrm{h}$ and freight train speeds of $120 \mathrm{~km} / \mathrm{h}$. (Valinluck, 2019). There will be 18 trains running during the day, including 4 passenger trains and 14 trains carrying freight. The passenger fare is $0.04 \mathrm{USD} /$ person $/ \mathrm{km}$ and the freight price is $0.07 \mathrm{USD} / \mathrm{don} / \mathrm{km}$ (Feng \& Qin, 2015).

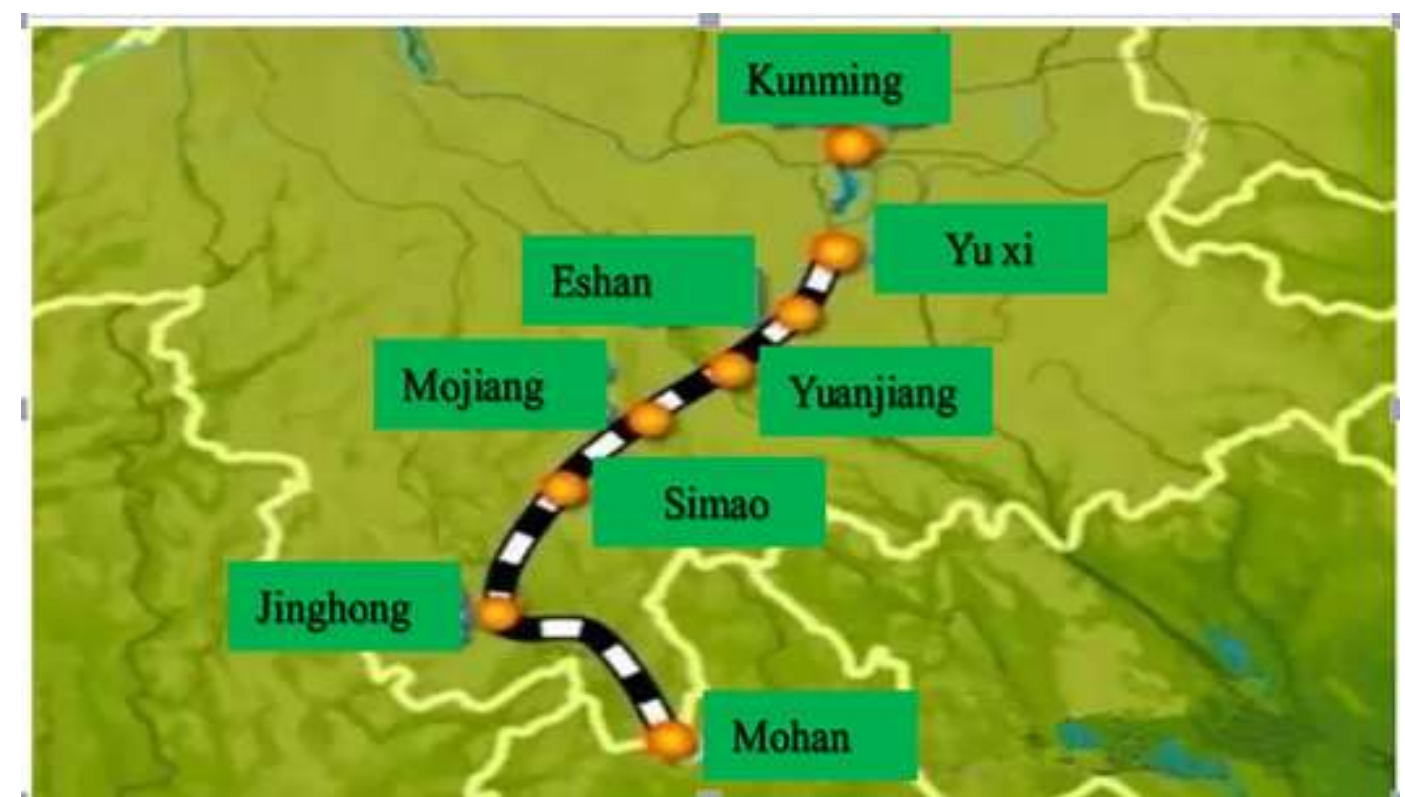


Figure 1. The station of the China-Laos railway in China. The map of Yunnan Province in China is in the background green.

Source: The author made an in-depth interview to the specific station information obtained from China Railway Bureau Group Co. Ltd, and then drew the figure 1 according to the map of Yunnan and the actual positions of each station

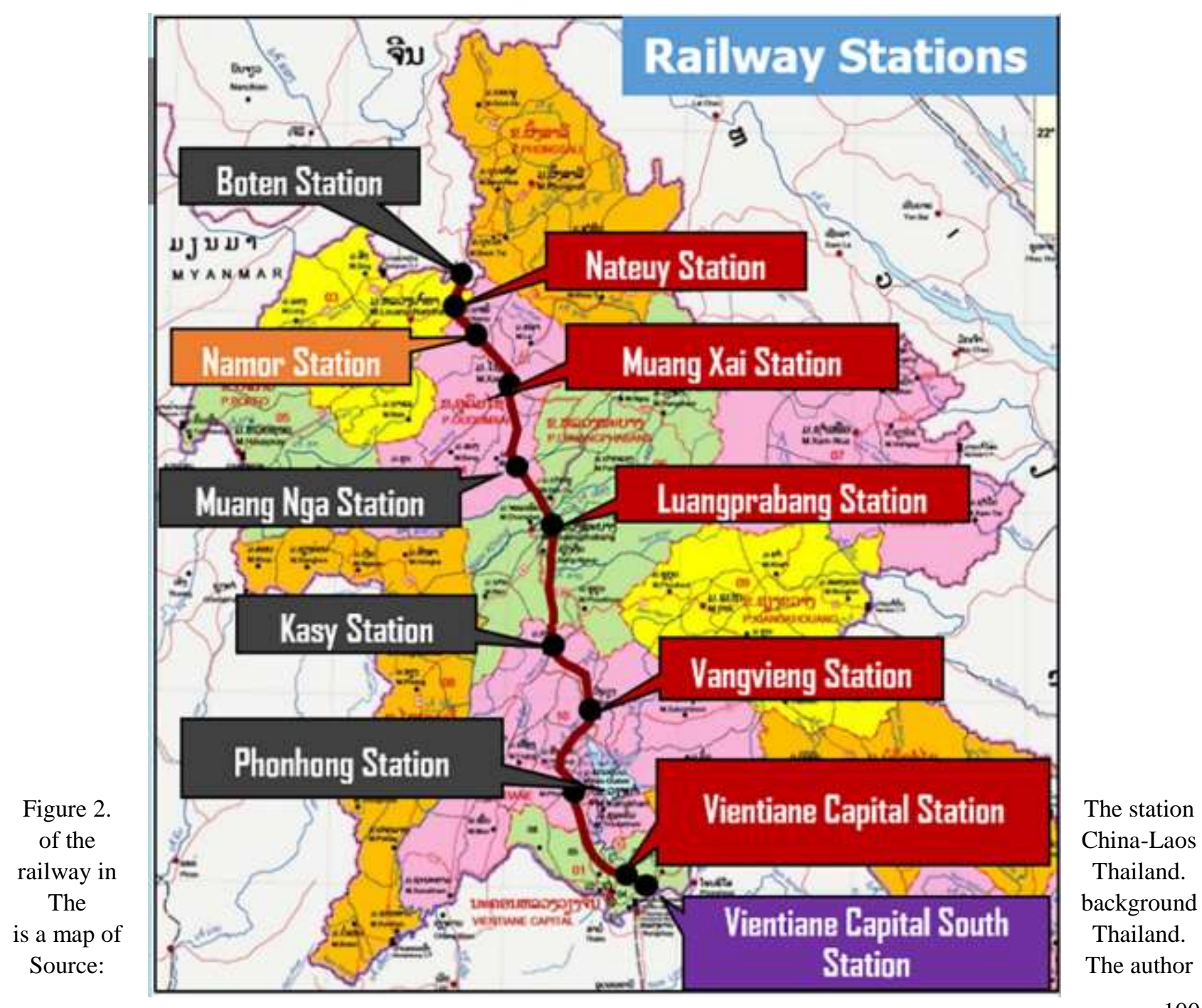

J. Bus. Econ. Review 6(1) 98 - 111 (2021) 
made an in-depth interview to the specific station information obtained from China Railway Rolling Stock Co. Ltd, and then drew the figure 2 according to the map of Yunnan and the actual positions of each station

\subsection{Thai products exported to the main provinces and routes in China.}

Thailand's products are mainly exported to 5 areas in China: Guangdong, Jiangsu, Shanghai, Shandong and Zhejiang. Guangdong imports reached $\$ 15.2$ billion in 2018 , accounting for $39 \%$ of the total exports, followed by the Yangtze River delta economic circle, the 3 major economic provinces of Jiangsu, Shanghai, Zhejiang, where imports accounted for 32\%. Jiangsu conducts $\$ 6.01$ billion in exports, accounting for 16\%, Shanghai is 4.68 billion, accounting for $12 \%$, and Zhejiang is 1.36 billion, accounting for $4 \%$. (Table 1). The main export products are plastic and rubber products, mechanical and electrical products, plant products. Plastic and rubber exports makes up 8.11 billion USD, accounting for 26.99\% (Sithirajvongsa, 2017). Mechanical and electrical products make up 6.826 billion USD, accounting for $22.71 \%$, and plant products makes up 3.284 billion USD, accounting for $12.80 \%$ (Table 2).

Table 1. Thai products exported to Chinese provinces.

\begin{tabular}{|c|c|c|c|c|c|c|}
\hline \multirow{3}{*}{ NO } & \multirow{3}{*}{ Province } & \multicolumn{5}{|c|}{ Thai Products Exported to Chinese Provinces (USD) } \\
\hline & & \multirow[t]{2}{*}{2016} & \multirow[t]{2}{*}{2017} & \multirow[t]{2}{*}{2018} & $\begin{array}{c}\text { Growth } \\
\text { Rate }\end{array}$ & \multirow[t]{2}{*}{ Proportion } \\
\hline & & & & & $(2017-2018)$ & \\
\hline 1 & Guangdong & $13,803,591,617$ & $13,260,389,838$ & $15,248,768,720$ & $15 \%$ & $39 \%$ \\
\hline 2 & Jiangsu & $5,632,824,482$ & $5,999,267,013$ & $6,014,308,982$ & $0.30 \%$ & $16 \%$ \\
\hline 3 & Shanghai & $4,487,400,808$ & $4,553,041,793$ & $4,683,007,972$ & $2.90 \%$ & $12 \%$ \\
\hline 4 & Shandong & $4,318,120,349$ & $4,091,297,618$ & $3,978,173,764$ & $-2.80 \%$ & $10 \%$ \\
\hline 5 & Zhejiang & $2,058,189,714$ & $1,586,880,942$ & $1,367,207,454$ & $-13.80 \%$ & $4 \%$ \\
\hline 6 & Others & $8,037,696,081$ & $7,685,594,349$ & $7,387,660,529$ & $-3.88 \%$ & $19 \%$ \\
\hline 7 & Total & $38,337,823,051$ & $37,176,471,553$ & $38,679,127,421$ & $4.04 \%$ & $100 \%$ \\
\hline
\end{tabular}

Source: General Administration of Customs, P.R. China

Table 2. The main components of Thailand's exports to China

\begin{tabular}{|c|c|c|c|c|}
\hline & \multicolumn{3}{|l|}{} & Units : Millions of dollars \\
\hline $\begin{array}{c}\text { The customs } \\
\text { classification }\end{array}$ & HS code & Commodity categories & In 2018 & Percentage \\
\hline Class 7 & $39-40$ & Plastic, rubber & 8113 & $26.99 \%$ \\
\hline Class 16 & $84-85$ & $\begin{array}{c}\text { Mechanical and electronic } \\
\text { products }\end{array}$ & 6826 & $22.71 \%$ \\
\hline Class 2 & $06-14$ & Plant products & 3284 & $12.80 \%$ \\
\hline Others & - & - & 11833 & 37.50 \\
\hline Category & Code & Total value & 30056 & $100 \%$ \\
\hline
\end{tabular}

Source: Ministry of Commerce of the People's Republic of China 
The 5 provinces are divided into 3 regions. The first is Guangdong, which is the south China economic center. Shanghai, Jiangsu, Zhejiang are the Yangtze River delta economic center, and Shandong, which is an important economic hub in northern China. Knowing the main industries and provinces that Thailand exports to China will enable us to identify the main transport routes. If it can be proved that the new routes formed after the completion of the China-Laos railway can improve the logistical performance of the Thai industry, thus helping the major industries to increase the volume of trade, this will assist in improving the competitiveness of Thailand's export industry.

The authors interviewed 8 companies (Table 3 ) and, in combination with other studies, identified some routes for examination. The 8 companies mainly use land transport and sea transport. R3A route, R9 route, and R12 route were adopted for land transportation for Guangdong. R3A is the Highway from Kunming to Bangkok. R9 and R12 are the highways from Bangkok to Nanning; they are the important transportation highways from Thailand to China (Valinluck, 2019). The other route is from Laem Chabang Port to Port of Guangzhou, Foshan, and Shenzhen Shekou Port by sea transport. This shipping line is an important sea transportation channel for other countries to enter China (Tian Zheng, 2016). For the 3 provinces of the Yangtze River Delta and Shandong province in the north, route R9 and route R12 can enter China from Nanning to these provinces by land transport (Thangthokit, 2009).

The 3 provinces of the Yangtze River Delta has 2 more routes: one is by sea to Foshan Port in Guangzhou, with a transfer to Shanghai by land. The other is a direct route by sea from Laem Chabang Port to Shanghai Port (Tian, 2016). Shanghai Port is the largest port in eastern China, an important hub for other countries to enter eastern and northern China by sea (Thangthokit, 2009). There are 3 transportation routes for Shandong province. The first is Laem Chabang Port to Hong Kong Port and finally to Qingdao Port. The second route is Laem Chabang Port to Kaohsiung Port and finally to Qingdao Port (Tao, 2017).

The third route is from Laem Chabang Port to Shanghai Port; including land transport to Shandong province from Shanghai port. Shandong province is in the north of China, and Thai exports to China are mainly by sea (Yangyang \& Li, 2020). These 3 sea lines are the only sea transportation routes. After the completion of the China-Laos railway, the new rail route will run from Bangkok to Nongkhai Station, then through Laos from The Vientiane South Station, through the Mohan Station to Kunming Station, finally through Chengdu Station to Shandong, Shanghai, Zhejiang, and Jiangsu provinces (T1, T2). For Guangdong province, it is directly from Kunming Station to Guangdong province (Su, 2018) (T3) (Table 4).

Table 3. Eight companies interviewed.

\begin{tabular}{|c|c|c|c|}
\hline NO & Company & Industry & Area \\
\hline 1 & Wanhai Shipping Co., LTD. & $\begin{array}{c}\text { Third-Part Logistics } \\
\text { Shipping) }\end{array}$ & Shandong \\
\hline 2 & Evergreen Marine Co., LTD & $\begin{array}{c}\text { Third-Part Logistics } \\
\text { Shipping })\end{array}$ & Shandong \\
\hline 3 & OOCL Shipping Co., LTD & $\begin{array}{c}\text { Third-Part Logistics } \\
\text { Shipping) }\end{array}$ & Shandong and Shanghai \\
\hline 4 & Baohan International Logistics Co., LTD & $\begin{array}{l}\text { Sell Thai plant products } \\
\text { and fruit products }\end{array}$ & Guangdong \\
\hline 5 & Cts International Logistics Co., LTD & $\begin{array}{l}\text { Third-Part Logistics } \\
\text { Shipping and Road })\end{array}$ & Guangdong and Shanghai \\
\hline 6 & Pawin Golden Rice Co., LTD & Thai rice & Guangdong and Nanning \\
\hline
\end{tabular}


Table 4. The main route for export transportation

\begin{tabular}{|c|c|c|}
\hline $\mathrm{R} 3 \mathrm{~A}$ & $\begin{array}{l}\text { Bangkok -Chiangkong-Houayxay (Laos)-Boten- } \\
\text { Mohan (China)-Jinghong-Kunming- }\end{array}$ & Guangdong \\
\hline R9 & $\begin{array}{c}\text { Bangkok-Mukdaharn-SavannaKhet(Laos)-Dansavanh- } \\
\text { Lao Bao (Vietnam)-Hanoi-LangSon-Huu Nghi-Nanning (China)- }\end{array}$ & Guangdong \\
\hline $\mathrm{R} 12$ & $\begin{array}{c}\text { Bangkok- Panom-Tha Kek (Laos)-Na Pao } \\
\text {-Cha Lo (Vietnam)-Hanoi-LangSon-Huu Nghi-Nanning (China)- }\end{array}$ & Guangdong \\
\hline S1 & $\begin{array}{l}\text { Bangkok- Chabang Port-Port of Guangzhou, Foshan (Shenzhen Shekou } \\
\text { Port)- }\end{array}$ & Guangdong \\
\hline $\mathrm{T} 1$ & $\begin{array}{l}\text { Bangkok-Nongkhai Station-The Vientiane South Station（Laos）-Mohan } \\
\text { Station (China)-Kunming Station- }\end{array}$ & Guangdong \\
\hline R9 & $\begin{array}{l}\text { Bangkok-Mukdaharn-SavannaKhet(Laos)-Dansavanh- } \\
\text { Lao Bao (Vietnam)-Hanoi-LangSon-Huu Nghi-Nanning (China)- }\end{array}$ & $\begin{array}{l}\text { Shanghai } \\
\text { Zhejiang } \\
\text { Jiangsu }\end{array}$ \\
\hline $\mathrm{R} 12$ & $\begin{array}{c}\text { Bangkok-Nakorn Panom-Tha Kek (Laos)-Na Pao } \\
\text {-Cha Lo (Vietnam)-Hanoi-LangSon-Huu Nghi-Nanning (China)- }\end{array}$ & $\begin{array}{l}\text { Shanghai } \\
\text { Zhejiang } \\
\text { Jiangsu }\end{array}$ \\
\hline S2 & Bangkok-Laem Chabang Port-Shanghai Port- & $\begin{array}{l}\text { Shanghai } \\
\text { Zhejiang } \\
\text { Jiangsu }\end{array}$ \\
\hline S3 & Bangkok-Laem Chabang Port-Port of Guangzhou, Foshan- & $\begin{array}{l}\text { Shanghai } \\
\text { Zhejiang } \\
\text { Jiangsu }\end{array}$ \\
\hline $\mathrm{T} 2$ & $\begin{array}{l}\text { Bangkok-Nongkhai Station-The Vientiane South Station (Laos) -Mohan } \\
\text { Station (China)-Kunming Station-Chengdu Station- }\end{array}$ & $\begin{array}{l}\text { Shanghai } \\
\text { Zhejiang } \\
\text { Jiangsu }\end{array}$ \\
\hline S4 & Bangkok-Laem Chabang Port-Hong Kong Port-Qingdao Port- & Shandong \\
\hline S5 & Bangkok-Laem Chabang Port-Kaohsiung Port-Qingdao Port- & Shandong \\
\hline S6 & Bangkok-Shanghai Port- & Shandong \\
\hline $\mathrm{T} 3$ & $\begin{array}{c}\text { Bangkok-Nongkhai Station-The Vientiane South Station (Laos) -Mohan } \\
\text { Station (China) -Kunming Station- }\end{array}$ & Shandong \\
\hline
\end{tabular}

Source: Wanhai Shipping Co., LTD., Evergreen Marine Co., LTD., OCL Shipping Co., LTD., Baohan International Logistics Co., LTD.

$\mathrm{R}=$ road $\quad \mathrm{T}=$ train $\mathrm{S}=$ ship

The authors found that the existing routes were mainly by land and sea. The new routes collected by the author will be able to be used by the Thai industry. Finally, it will be proved by comparison that the new route will be superior to the existing one. 


\subsection{Determining the driving factors for route selection.}

The selection of a route is one of the most important factors in transportation. However, the selection of a transportation route is a complex and multi-criteria decision. The authors have to consider many different factors, such as distance, cost, delivery time, security, transportation capability, and so on (Table 5). The authors collected 19 literature reviews using a second-hand data method and summarized the driven factors of the selected route they adopt. Cost and time are the most frequently used factors in other literature, followed by security and transportation capacity, and finally distance (Etoh \& Sakurai, 2011; Fareed, 2012; Gong \& Wu, 2007; Guan, 2014; Huang, 2020; Jia-ni \& Yong-ping, 2015; Lei, 2014; Zhu \& Chen, 2013; Wang, 2014).

Table 5. Summary of the Driving Factors

\begin{tabular}{|c|c|c|c|c|c|c|}
\hline Author (year) & Distance & Cost & Time & Security & $\begin{array}{c}\text { Transportation } \\
\text { capacity }\end{array}$ & others \\
\hline $\begin{array}{c}\text { MaciejHojda } \\
\text { 2018) }\end{array}$ & & $\sqrt{ }$ & $\sqrt{ }$ & & $\sqrt{ }$ & \\
\hline $\begin{array}{c}\text { MaciejHojda } \\
\text { 2020) }\end{array}$ & & $\sqrt{ }$ & $\sqrt{ }$ & $\sqrt{ }$ & & \\
\hline $\begin{array}{c}\text { Etoh \& Sakurai } \\
\text { (2011) }\end{array}$ & & $\sqrt{ }$ & $\sqrt{ }$ & & & $\sqrt{ }$ \\
\hline Fareed (2012) & $\sqrt{ }$ & $\sqrt{ }$ & $\sqrt{ }$ & & $\sqrt{ }$ & \\
\hline $\begin{array}{c}\text { Gong, \& Wu, } \\
\text { (2007) }\end{array}$ & $\sqrt{ }$ & $\sqrt{ }$ & $\sqrt{ }$ & & & \\
\hline Guan (2014) & $\sqrt{ }$ & $\sqrt{ }$ & $\sqrt{ }$ & $\sqrt{ }$ & & $\sqrt{ }$ \\
\hline Huang (2020) & & $\sqrt{ }$ & & $\sqrt{ }$ & $\sqrt{ }$ \\
\hline Cheng (2011) & $\sqrt{ }$ & $\sqrt{ }$ & $\sqrt{ }$ & $\sqrt{ }$ & $\sqrt{ }$ \\
\hline Jia ni(2015) & $\sqrt{ }$ & $\sqrt{ }$ & $\sqrt{ }$ & $\sqrt{ }$ & \\
\hline Lei (2014) & & $\sqrt{ }$ & $\sqrt{ }$ & $\sqrt{ }$ & \\
\hline Zhu (2009) & & $\sqrt{ }$ & $\sqrt{ }$ & $\sqrt{ }$ & \\
\hline Liu (2006) & & $\sqrt{ }$ & $\sqrt{ }$ & $\sqrt{ }$ & \\
\hline Xie(2009) & & $\sqrt{ }$ & $\sqrt{ }$ & $\sqrt{ }$ & \\
\hline Ji (2012) & & $\sqrt{ }$ & $\sqrt{ }$ & & $\sqrt{ }$ & \\
\hline Zang (2013) & $\sqrt{ }$ & & $\sqrt{ }$ & & $\sqrt{ }$ & \\
\hline Tian (2016) & & $\sqrt{ }$ & $\sqrt{ }$ & & $\sqrt{ }$ & \\
\hline Lei (2014) & $\sqrt{ }$ & & $\sqrt{ }$ & $\sqrt{ }$ & \\
\hline Wang (2014) & & $\sqrt{ }$ & $\sqrt{ }$ & & & \\
\hline Zhu (2013) & $\sqrt{ }$ & $\sqrt{ }$ & $\sqrt{ }$ & & \\
\hline Total 19 & 7 & 17 & & & \\
\hline
\end{tabular}




\section{Research Methodology}

\subsection{Research Flowchart}

This chapter presents the research method, which encompasses 5 steps, and the methodology framework of this research as depicted in Figure 3.

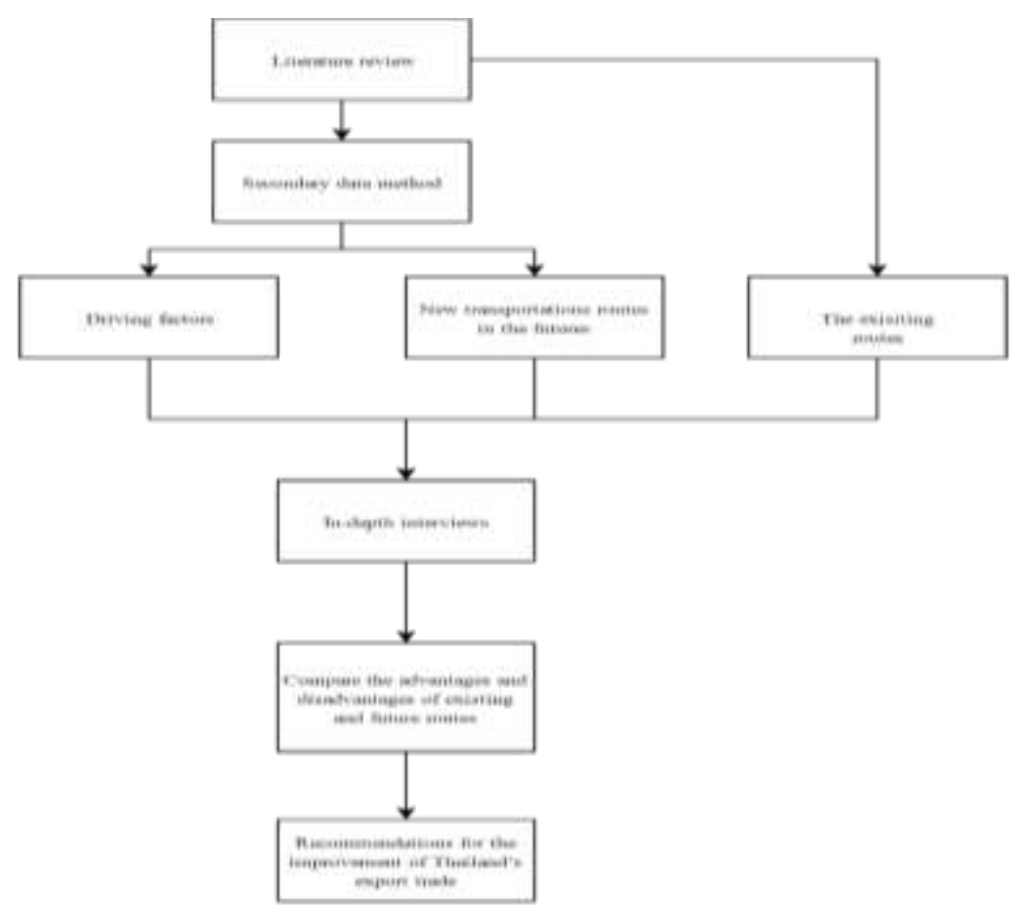

Figure 3. Research Flowchart

Step 1: Identify the existing major transportation routes through a literature review and in-depth interviews.

Step 2: Use secondary data analysis to identify the driving factors and the new transportation routes after the completion of the railway.

Step 3: Use in-depth interviews to compare the existing routes with the new route based on the main factors.

Step 4: Identify the advantages and disadvantages of these routes.

Step 5: Make recommendations for the improvement of Thailand's export trade to China.

\subsection{In-depth interview}

1. In-depth interviewing is a qualitative research technique that involves conducting intensive individual interviews with a small number of respondents to explore their perspectives on a 
particular idea, program, or situation. In-depth interview is an unstructured, direct, one-on-one method of data collection. The author identified 3 methods to adopt during the interviews: specific questions, open-ended questions, probing questions. The author interviewed the experts and professionals on the following issues:

2. A leading export company for main industries: This company has a certain scale, China is an important customer of the company, the company has been engaged in import and export trade between China and Thailand for a long time.

3. A leading freight forwarding company: This company has land and sea transportation business from Thailand to China, and sea freight forwarding business can cover the major economic and trade provinces of China. Since some industrial companies do not have their own logistics systems and need third-party logistics, these logistics companies will also know the main routes and which industries are suitable for which routes.

4. Experts in the field of logistics: Expert 1: The expert has been engaged in education and research in the field of logistics for many years and has a deep understanding of the trade and transportation between China and Thailand. Expert 2: He is good at studying border trade and understands the most common modes and routes of transportation between China and Thailand. Expert 3: Head of the National Key Project ("A study to develop a strategic plan for supporting Laos-China Railway construction project (Boten-Vientiane)") Team in Thailand.

\subsection{Secondary data analysis}

Secondary data analysis involves a researcher using the information that someone else has gathered for his or her own purposes. Researchers leverage secondary data analysis in an attempt to answer a new research question, or to examine an alternative perspective on the original question of a previous study. This paper will obtain the export routes used by major industries based on a literature review and will then conduct indepth interviews with companies and experts in related industries. Finally, the author will use the secondhand data method to screen out the most frequently used and most appropriate routes for these main industries at present. These routes will be compared with the new routes formed after the completion of the China-Laos railway.

\section{Results and Discussion}

The general results of this research are summarized below. The authors used the secondary data method to identify the driving factors, then employed them in in-depth interviews with 8 companies. These companies are famous freight forwarding companies from Guangdong, Shanghai, and Shandong. They combined these factors with the specific shipping conditions of the company (FENG, 2020). They argued that distance need not be taken into account when comparing routes. The convenience, which refers to the time of customs clearance for each transportation route, road conditions on each route and weather, should be taken into consideration (Rusakova \& Bylkov, 2018). Further, the convenience of transportation to the distributor after the goods arrive at the destination is also relevant. The authors interviewed transportation companies and obtained their opinions on these routes, which are summarized below. 
Factor

cost

time

Convenience

Security

Transport capacity

time

Convenience
Table 6. Summary of the Expert opinions for Guangdong opinion

ranking

From interviews with the company forecast, land transport cost is $0.12-\$ 0.15 / \mathrm{mt} / \mathrm{km}$, and the cost of the train is $\$ 0.7 / \mathrm{mt} / \mathrm{km}$, the shipping cost is $0.02-\$ 0.03 / \mathrm{mt} / \mathrm{km}$, due to the five routes of Guangdong, the distance is similar, so the new line will be better than other land transportation route, but the cost is higher than the shipping route.

As for the time, due to the slow speed of shipping, loading, and unloading, the shipping time is the longest. The speed of the railway is $120 \mathrm{~km} / \mathrm{h}$, and it can reach $160 \mathrm{~km} / \mathrm{h}$ after entering China, which is also much higher than the speed of the automobile.

About convenience, after customs clearance is completed in NongKhai, Thailand, the new route will be able to enter China directly by train. While the rest of road transport to the boundary of two or more formalities, and due to the different driving direction of Laos and Vietnam and Thailand, trucks have to be changed, load and unload repeatedly. Road conditions are bad, and land transportation customs clearance formalities are complicated. However, sea transportation is limited by the "door to door" transport, and it is greatly affected by the weather, so the convenience of the new route is more advantageous.

The road route is affected by the poor road condition in Laos, so the safety performance is low, while the sea route has to consider the Gulf of Thailand, where shipping is often cancelling due to the weather, so the railway has the highest safety performance.

The transport capacity of one carriage of the train is 50 tons, a train has 15-20 carriages, the transport capacity of the ship is between 4000-5000 tons, and the transport capacity of the ordinary truck is between 20-30 tons.
S1>T1>(R3A-R9-R12)

T1 $>($ R3A-R9-R12) $>$ S1

T1 $>$ S1>(R3A-R9-R12)

T1 $>($ R3A-R9-R12) $>$ S1

$\mathrm{S} 1>\mathrm{T} 1>(\mathrm{R} 3 \mathrm{~A}-\mathrm{R} 9-\mathrm{R} 12)$

Table 7. Summary of the Expert opinions for the Yangtze River delta economic center

$\begin{array}{cl}\text { Factor } & \text { opinion } \\ \text { cost } & \text { From interviews with the company forecast, land transport }\end{array}$
cost is $0.12-\$ 0.15 \mathrm{mt} / \mathrm{km}$, and the cost of the train is $\$ 0.7$ $/ \mathrm{mt} / \mathrm{km}$, the shipping cost is $0.02-\$ 0.03 / \mathrm{mt} / \mathrm{km}$, Sea transportation is the shortest, followed by land transportation and railway transportation similar, so sea transportation has an obvious advantage in cost

As for the time, due to the slow speed of shipping, loading, and unloading, the shipping time is the longest. The speed of the railway is $120 \mathrm{~km} / \mathrm{h}$, and it can reach $160 \mathrm{~km} / \mathrm{h}$ after entering China, these three cities all have their own railway stations, all can go directly to the destination, so time on the railway is the most advantageous.

Land transportation is not only limited by the road conditions in Laos, after entering China, there are no good ranking

$\mathrm{S} 2>\mathrm{S} 3>\mathrm{T} 2>(\mathrm{R} 9 \mathrm{R} 12)$

$\mathrm{T} 2>(\mathrm{R} 9-\mathrm{R} 12)>\mathrm{S} 2>\mathrm{S} 3$

$\mathrm{T} 2>\mathrm{S} 2>\mathrm{S} 3>(\mathrm{R} 9 \mathrm{R} 12)$ 
expressways through Sichuan province and Chongqing Province, while sea transportation will be affected by the weather due to the long shipping time, so the railway is also the most convenient.

Security The road route is affected by the poor road condition in Laos, so the safety performance is low, while the sea route has to consider the Gulf of Thailand, where shipping is often cancelling due to the weather, so the railway has the highest safety performance.

Transport capacity The transport capacity of one carriage of the train is 50 tons, a train has 15-20 carriages, the transport capacity of the ship is between 4000-5000 tons, and the transport capacity of the ordinary truck is between 20-30 tons.

Table 8. Summary of the Expert opinions for Shandong

Factor cost opinion

The cost per kilometer of the new route is higher than that of other sea transportation routes. Shandong is also a neighboring city in the north, and the distance of railway transportation is much longer than that of sea transportation. All the lines cannot be directly connected, and all routes need to be changed, so other sea transportation has cost advantages compared with other sea transportation.

time Because of the long-distance transportation, the speed of the railway is fast, so the advantage of short time is more reflected, so the railway has the advantage.

Convenience The transshipment port is needed, and the shipping capacity is large, so unloading and loading are extremely inconvenient. By contrast, the train only needs to change the track, and the railway will be more convenient to handle in the customs formalities.

Security The sea transportation will be affected by the weather, and the Taiwan Strait is not navigable due to the relationship between Mainland China and Taiwan, so the safety of railway transportation has a great advantage.

Transport capacity The transport capacity of one carriage of the train is 50 tons, a train has 15-20 carriages, the transport capacity of the ship is between $4000-5000$ tons

$\mathrm{T} 2>(\mathrm{R} 9 \mathrm{R} 12)>\mathrm{S} 3>\mathrm{S} 2$

$\mathrm{S} 2>\mathrm{S} 3>\mathrm{T} 2>(\mathrm{R} 9 \mathrm{R} 12)$

ranking

$\mathrm{S} 4>\mathrm{S} 5>\mathrm{S} 6>\mathrm{T} 3$

$\mathrm{T} 3>\mathrm{S} 6>\mathrm{S} 5>\mathrm{S} 4$

$\mathrm{T} 3>\mathrm{S} 4>\mathrm{S} 5>\mathrm{S} 6$

$\mathrm{T} 2>(\mathrm{R} 9 \mathrm{R} 12)>\mathrm{S} 3>\mathrm{S} 2$

$\mathrm{S} 2>\mathrm{S} 3>\mathrm{T} 2>(\mathrm{R} 9 \mathrm{R} 12)$

It can be seen from the results that the new routes formed after the establishment of the China-Laos railway have great advantages for convenience, time, and safety. They are also superior to other routes in terms of cost and transportation capacity $(\mathrm{Li}, 2015)$.

\section{Conclusion}

The authors summarize the main industry and the exporters of Thai products to China through the literature review, identifying the primary modes of transport as land transportation and sea transportation. Hence, the establishment of the China-Laos railway will likely change the industry transportation route. The authors combined the literature review and in-depth interview method to select the current transport routes 
and summarize the main factors of the comparative route. These were identified as: time, convenience, security, transport capacity, and cost. Finally, the collected data was used to compare these routes based on these factors. When exporting goods to the provinces of Guangdong and the Yangtze River economic circle, the new routes costs less per kilometer than land transportation and takes less time than all other routes. If plant products are transported, freshness of plants can be guaranteed, and costs can be reduced.

Due to different driving rules, vehicles used for land transport need to be changed, while the shipping needs to stop at the port for turnover, which is not required for the new route (Sir-Innop, 2016). The customs clearance procedures can also be arranged directly in one step, instead of going through both the Laos customs and the Chinese customs, and shipping needs to stop at the port for turnover, but the new routes does not need to do this. Trains are also more capable and safer than vehicles. When exporting products to Shandong province, sea transportation needs to be changed at the port twice, thereby increasing the time taken to transport the goods.

The long time spent at sea will be far less safe than the new route, and natural rubber and plant products will also be damaged, meaning costs will increase. China has great advantages in time, safety, and convenience. It also has more advantages than land transport in terms of cost and transport capacity. Therefore, the China-Laos railway was built. After the completion, the new routes will help the industry improve the export volume of product and industrial competitiveness. These new routes discussed in this paper will also provide a reference for other companies and industries, making it more convenient for conducting business. After knowing the situation of the new route, China and Thailand can also develop their economy according to the railway situation (Shansong \& Xiuying, 2018).

Moreover, railways are limited by on-time performance, taking into account the requirements of full load and punctuality. On the one hand, relevant Chinese and Thai enterprises need to strengthen the development of third-party logistics businesses that provide services along these routes, so that logistics and transportation can be standardized, and procedures can be handled more quickly (Wang \& Zhang, 2014). Further, Thailand needs to train more railway transport-related talents, which will provide convenience for many small and medium-sized enterprises. On the other hand, plant products are also important export products of Thailand, and many plant products need cold chain logistics. Therefore, many large enterprises and freight forwarding companies should take this business into consideration and facilitate the development of the China-Laos railway and the export development of Thailand's major industries.

\section{References}

Bin, T., \& Mengrong, L. (2018). On the Translation of High-speed Railway Promotional Film from the Perspective of Multi-modal Theory --A Case Study of 2015 China High-speed Railway Promotional Film. Paper presented at the The 6th International Symposium on Innovation and Sustainability of Modern Railway.

Etoh, F., Hori, Y., \& Sakurai, K. (2011, July). A study of communication route selection considering route security. In 2011 IEEE/IPSJ International Symposium on Applications and the Internet (pp. 360-365). IEEE.

Fareed, M. S., Javaid, N., Ahmed, S., Rehman, S., Qasim, U., \& Khan, Z. A. (2012, November). Analyzing energyefficiency and route-selection of multi-level hierarchal routing protocols in WSNs. In 2012 Seventh International Conference on Broadband, Wireless Computing, Communication and Applications (pp. 626-631). IEEE.

Feng, B., \& Qin, S. (2015, January). The Performance Evaluation of China Railway Corporation Modern Logistics Based on Combination Weighting Method and TOPSIS Method. In International Conference on Education, Management, Commerce and Society (EMCS-15) (pp. 627-631). Atlantis Press.

Feng, S. M. (2020). International Aviation Logistics Risk Identification and Assessment from Perspective of Consolidator Based on AHP. DEStech Transactions on Engineering and Technology Research, (acaai).

Gong, Y. W., \& Wu, Q. (2007). Study on Path Selection of Emergency Logistics Based on AHP [J]. Logistics Sci-Tech, 9, 90-92. 
Guan, Y. M. (2014). Applied AHP Technology and Information Technology in Evaluation for Teaching Quality of University. In Advanced Materials Research (Vol. 1022, pp. 229-232). Trans Tech Publications Ltd.

Huang. (2020). Study on the selection of logistics transportation route between cities based on AHP. The electronic commerce (4), 5-6,8.

Jia-ni, G., \& Yong-ping, G. (2015, December). Comparative study of credit rating of SMEs based on AHP and KMV model. In 2015 Joint International Social Science, Education, Language, Management and Business Conference. Atlantis Press.

Lei, L. (2014, October). Study on the Fire Risk Assessment of the Electric Bicycle Based on the AHP. In $20147 t h$ International Conference on Intelligent Computation Technology and Automation (pp. 729-732). IEEE.

Li, L., Guan, C., Liu, X., Xu, Y., Du, A., Liu, Y., ... \& Gao, Y. (2019, April). Research on Evaluation Model of Full Voltage Level Operation Efficiency of Provincial Power Grid Using Analytic Hierarchy Process (AHP). In 2019 International Conference on Modeling, Simulation, Optimization and Numerical Techniques (SMONT 2019) (pp. 5154). Atlantis Press.

Li, Q. (2015). Evaluation of Transit Service Quality for Urban Railway on the Basis of AHP-A Sample of ZHUHAI Station in Beginning Stage. In Applied Mechanics and Materials (Vol. 743, pp. 673-678). Trans Tech Publications Ltd.

Rusakova, O., \& Bylkov, V. (2018). The Social and Economic Aspects of the Employment in Railway Transport of China. Paper presented at the The 6th International Symposium on Innovation and Sustainability of Modern Railway (ISMR2018)

Shansong, H., \& Xiuying, L. (2018). Analysis on Competitive Advantages and Global Marketing Strategies of China's High-speed Railway. Paper presented at the The 6th International Symposium on Innovation and Sustainability of Modern Railway

Sithirajvongsa, T. (2017). The impact of the China-Laos railway on the development of Laos. (master's degree). Lanzhou University,

Sri-Innop, K. (2016). The Determination of Merchandise Trade Between Thailand and China. (master's degree). Southeast University,

Su. (2018). Problems Diagnosis and Countermeasure Research of Lao Chinese Railway Project. (master's degree). Capital University of Economics and Business,

Tao. (2017). Discussion on Logistics Development of China-Laos Railway International Intermodal Transport Channel under the Belt and Road Initiative. Railway freight, 35(10), 20-24.

Tian. (2016). Research on Logistics Transportation Mode Selection of Jindong Paper Company Based on AHP. (master's degree). Guizhou university,

TianZheng. (2016). Research on vehicle routing selection for emergency supplies based on AHP. 216(21), $284-284$.

Thangthokit, J. (2009). FTA Thailand-China : Opportunities and Obstacles of Thailand's Export to China. (master's degree). Southeast University

Valinluck, T. (2019). Impacts of ASEAN--China Free Trade Agreement (ACFTA)on Thailand's trade with China. (master's degree). University of International Business and Economics,

Wan, J., Qi, G., Zeng, Z., \& Sun, S. (2011, June). The application of AHP in oil and gas pipeline route selection. In 2011 19th International Conference on Geoinformatics (pp. 1-4). IEEE.

Wang, W., Chen, J., Chen, Y., \& Chen, Y. (2014, October). Research on performance evaluation and reconstruction strategy of transforming enterprise cooperation network based on G-AHP. In 2014 IEEE International Conference on Systems, Man, and Cybernetics (SMC) (pp. 2044-2049). IEEE.

Wang, Y., Liang, L., \& Zhang, J. (2014, December). Based on the Factor Analysis and AHP Online Shopping Satisfaction Evaluation Research. In 2014 Seventh International Symposium on Computational Intelligence and Design (Vol. 2, pp. 362-366). IEEE.

Wei, D. C. (2010, August). Implementation of route selection function based on improved Floyd algorithm. In 2010 WASE International Conference on Information Engineering (Vol. 2, pp. 223-227). IEEE.

Wang, X., \& Li, X. (2015, April). Optimization of the Inventory Control Model of Auto Enterprise Parts Based on AHP. In 2015 International Conference on Mechatronics, Electronic, Industrial and Control Engineering (MEIC-15) (pp. 189-193). Atlantis Press. 
Liu, X. L., \& Cheng, W. (2009, April). Application of Dynamic Route Selection Model in Urban Transportation Distribution. In 2009 International Conference on Measuring Technology and Mechatronics Automation (Vol. 3, pp. 486-489). IEEE.

Yangyang, \& Li. (2020). Research on the Influence of International Railway Opening on Cross-border Logistics Accessibility and Economic Connections _- Take the China-Laos railway as an example. Journal of Chongqing University of Technology, 34(4), 24-32.

Ding, Y. L., Ren, P., Zhao, H. W., \& Miao, C. Q. (2018). Structural health monitoring of a high-speed railway bridge: five years review and lessons learned. Smart Structures and Systems, 21(5), 695-703.

Zhang, Y. P., Song, C. J., Yang, Z. C., \& Zhang, W. (2012). Research on Route Selection Model of Road Network Emergency Evacuation under Ice and Snow. In Advanced Engineering Forum (Vol. 5, pp. 144-149). Trans Tech Publications Ltd.

Qiao, Y., Han, D., Shen, J., \& Wang, G. (2014, October). A study on the route selection problem for ship evacuation. In 2014 IEEE International Conference on Systems, Man, and Cybernetics (SMC) (pp. 1958-1962). IEEE.

Zhangjie, Wang, \& Zhang. (2019). Impact of China-Laotai-Thailand Railway Construction on Spatial Connection Pattern of Yunnan Province and Countries Along the Line. World Regional Studies, 28(3), 43-53.

Zhu, H. Z., \& Chen, Y. Q. (2013). Route Selection of Expressway Based on VE and AHP. In Applied Mechanics and Materials (Vol. 357, pp. 2420-2425). Trans Tech Publications Ltd. 